\title{
Arthrogryposis Multiplex Congenita - Case Report
}

\author{
Faton Krasniqi ${ }^{1}$, Shpetim Salihu ${ }^{1}$, Isabere Krasniqi ${ }^{3}$, Edmond Pistulli ${ }^{2 *}$ \\ ${ }^{1}$ University Clinical Center of Kosova- Neonatology Clinic, Prishtina \\ ${ }^{2}$ Faculty of Technical Medical Sciences, University of Medicine, Tirana-Albania \\ ${ }^{3}$ Main Head Family Center, Prishtina-Kosovo \\ *epistulli@yahoo.com
}

\begin{abstract}
Arthrogryposis multiplex congenita is a rare disorder that accompanies with multiple joint contractures, which can occur at delivery and are non progressive. It affects both sexes. Most of the cases have been reported from Asia, Africa and Europe. Incidence is about 1:3000 to 1:10.000 of all live newborns. The causes, for now are unknown. However, this disorder can be provoked from neuropathic and myopathic diseases or some another cause that decreases the mobility of fetal joints. Great joints of both extremities are more attacked. The muscles of the extremities that are attacked can be hypoplastic. Also, the IQ of these children can be affected. We have presented a newborn female, born in term, by normal delivery, with arthrogryposis multiplex congenita, that has been resuscitated in delivery room and endotracheal intubation was needed. In utero, there has been a suspicion from the gynecologists at the end of pregnancy, for esophageal atresia. After delivery, all the needed consults and examinations have been realized. After three weeks in Neonatal Intensive Care Unit, the baby has been discharged in a better general condition, with recommendations to further consultations with orthopedics, physiatrician and pediatrician-neurologists.
\end{abstract}

Key words: arthrogryposis, multiple contractures of joints, congenital defect

\section{INTRODUCTION}

Arthrogryposis multiplex congenita refers to a heterogeneous group of congenital defects that manifests with multiple joint contractures (1). It characterizes with joint deformities with thin articular capsule, poor development and muscular contractures around affected joint, and the sensitive part is not affected. The incidence is rare, 1:3000-1:10.000 of all live newborn (2). In many cases the etiology is unknown, but intrauterine decrease of fetal movements may be caused from different diseases. Arthrogryposis multiplex congenita can be accompanied also with other anomalies, more often with ones of respiratory and urinary tract (3). Ophthalmologic abnormalities are also known such as Möebius syndrome, extra ocular muscles paralysis, congenital cataract and congenital or juveniles glaucoma (4), while corneal abnormalities are rarely reported (5).

\section{CASE REPORT}

We have presented a female newborn of a 25 years old primiparous mother, from a controlled pregnancy-up to 8 controls. She denies any disease during the pregnancy, except that at the $38^{\text {th }}$ week of gestation a gynecologist reveals polyhydramnion, and the patient was referred at our tertiary center for the suspicions of esophageal atresia. At $38^{\text {th }}$ week of gestation, vaginal delivery was induced and amniotic fluid was clear, birth weight 2900 gram, length $52 \mathrm{~cm}$, head circumference $35 \mathrm{~cm}$. Apgar score was 3 and 5 , in $1^{\text {st }}$ and $5^{\text {th }}$ minute, respectively. 

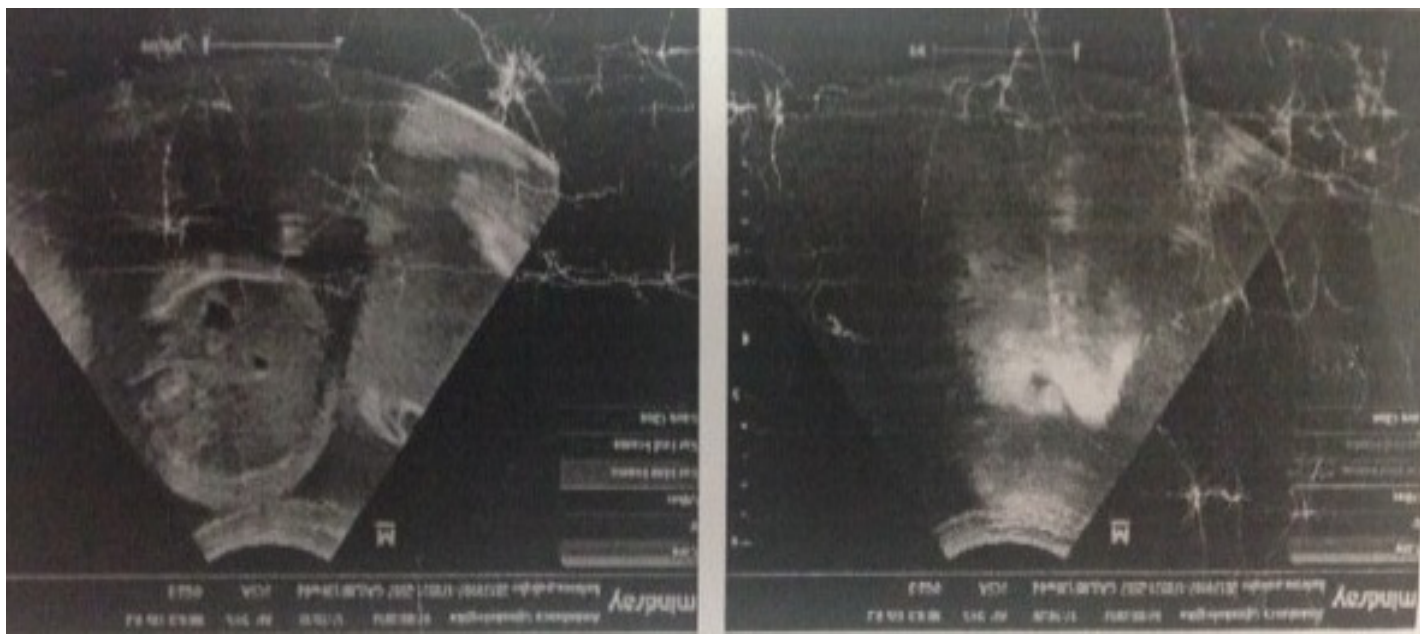

Fig1. Fetus condition at 30 th week of gestation

Newborn was resuscitated in delivery room, first with ambu-mask, but baby had still difficulties with breathing, and intubation was done and immediately was brought to our Intensive Care Unit. The newborn was put in mechanical ventilation with oxygen concentrations $-50 \%$ and respiratory rate of $45 / \mathrm{min}$. Afterwards, orogastric tube has been put, esophageal, gaster and duodenum passage has been realized, and esophageal atresia was excluded.

After the baby was stabilized the contractures of great and small joints of both upper and down extremities were noted. In addition, clinodactily of the second finger in both hands was also present.

The baby needed mechanical ventilation for three days, and then continued on nasal CPAP, for five days. At the beginning the baby was feed through orogastric tube and afterward with bottle.

Routine laboratory analyses were as follows: leukocytes- $14.8\left(10^{3} \mu / \mathrm{L}\right)$, erythrocytes- $4.40\left(10^{6} / \mu \mathrm{L}\right)$, hemoglobin$147 \mathrm{~g} / \mathrm{dL}$, thrombocytes-223 $\left(10^{3} / \mu \mathrm{L}\right)$, lymphocytes - 31.6\%, neutrofiles - $62.3 \%$, BUN - $8.12 \mathrm{mmol} / \mathrm{L}$, creatinine - $99.2 \mu \mathrm{mol} / \mathrm{L}$, total bilirubin $151.8 \mu \mathrm{mol} / \mathrm{L}$, direct bilirubin $-11.0 \mu \mathrm{mol} / \mathrm{L}$, total proteins $54.4 \mathrm{~g} / \mathrm{l}$, albumins $32.6 \mathrm{~g} / \mathrm{l}$, C reactive protein- $13.2 \mathrm{mg} / \mathrm{L}$, ALT- $91 \mathrm{U} / \mathrm{l}$, AST- $71 \mathrm{U} / \mathrm{l}$. Because of positive $\mathrm{C}$ reactive protein, neutrophilia and baby's general condition initial antibiotherapy with Ampicilin and Gentamycin were administrated. The fluids have been administrated according to the protocols.

Further consultation and examinations with orthopedists and physiatrists were planed. Orthopedists and physiatrists have suggested starting with exercises, and the goal of treatment is an extended knee for ambulation. As the patient had extension deformity of the knee, they suggested that this is more easily to be accomplished compared to flexion deformities (fig 2). However, moderate contractures of knees, up to $20-60^{\circ}$ (that were diagnosed in our case), need soft-tissue releases, including posterior capsulotomy of the knee joint, followed by long-term bracing, hence the intervention might be needed in the future.

Furthermore, she had mild hip flexion contracture that is acceptable for ambulation. Indeed, a flexion contracture was greater than $35^{\circ}$, which will require soft-tissue releases.

Clinodactily of both second hand fingers with moderate flexion deformities will require passive stretching and splinting.

Upper extremities will need treatment to develop self-help skills for feeding itself and use of toilet, and afterwards mobility skills. The patient will be followed up by Orthopedists and physiatrists and in case of needed for surgery, it should be considered after 5-6 years. 


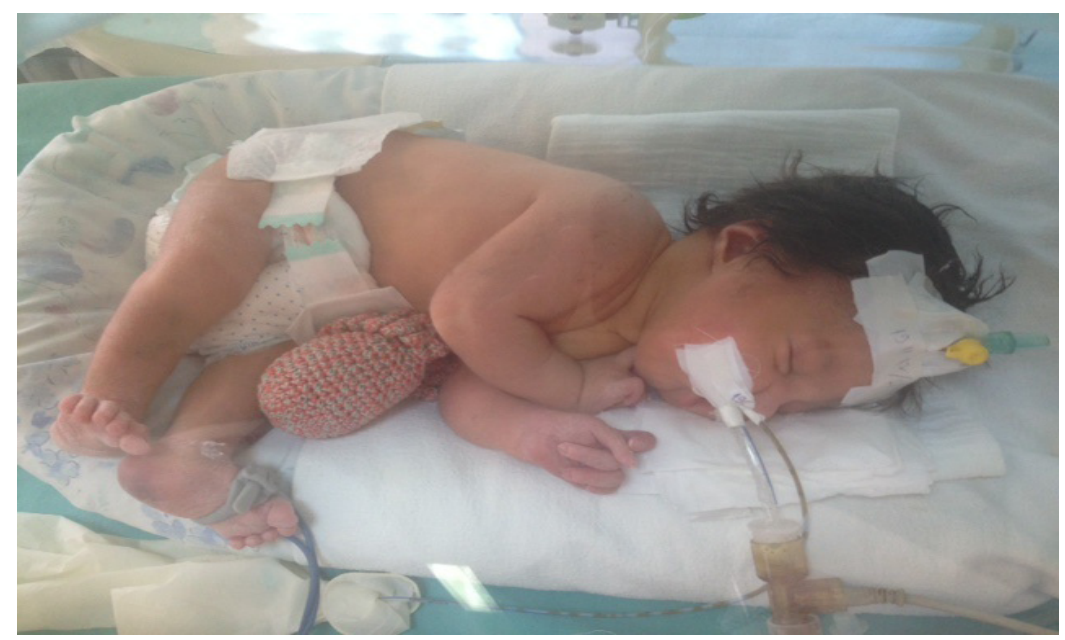

Fig2. Newborn with arthrogryposis multiplex congenita, immediately after birth.

Additional examinations were made. Echosonography of central nervous system did not found any pathological findings. Echocardiography revealed foramen ovale apertum. Abdominal echosonography findings were within normal limits. Hence, possible abnormalities according to the system organs have been excluded.

After the remission of general condition (sterile blood culture, negative $\mathrm{C}$ reactive protein), the antibiotherapy was stopped and the baby was transferred to the mother's bed. Feeding was advanced gradually day by day, according to the protocols, and the baby started to gain weight.

After the realization of all needed examinations and consultations the baby has been discharged in a relatively stable general condition, with recommendations for continuous treatment from other experts of different fields.

\section{Discussion}

Arthrogryposis multiplex congenita is a rare congenital syndrome that manifests clinically with contracture and multiple joint deformities (6). Incidence is 1:3000-1:10.000 of live newborn $(7,8)$. It is not a specific disease, but more accurately is prescribed as a clinical condition. It is accompanied with more than 300 different congenital disorders.

Arthrogryposis multiplex congenita is prescribed for the first time by Otto in 1841 at a full term newborn, with multiple joint contractures (9). Referred from Rocher this condition has been prescribed as "multiple congenital articular rigidity" and the hypothesis that reduction of fetal movements was responsible (10). Term Arthrogryposis multiplex congenita is prescribed also from Sterni in 1923 at its referees" hooked joints as a characteristic of disease (11).

Normally, fetal movements can be evidenced as early from 7-8 week of gestational age (12). Hence, prenatal diagnosis of arthrogryposis is possible. The lack of fetal movements with the difficult flexion and deformities of 4 extremities, accompanied with polyhydramnion, suggests a bad prognosis. Usual associated abnormalities are palatoschisis, meningocelae, congenital heart diseases, Klippel Feil syndrome etc. (13). Arthrogryposis multiplex congenita in found more often in pregnant women with type 1 diabetes (insulin dependent) (14).

Moreover, joint contracture can occur as a complex group, with heterogeneous congenital anomalies (Tab1).

Etiology of Arthrogryposis remains unknown, but many factors can interfere. Neuropathic, myopathic diseases, fetal joint abnormalities and restriction of intrauterine space lead in a decrease fetal movements and secondary 
contractures (15). Neuropathic diseases are usually the most common cause, in more than $90 \%$ of cases. Primary myopathic diseases can occur in $5-10 \%$ of cases.

Arthrogryposis multiplex congenita is characterized with multiple articular rigidity that are present from the birth. Usually joints are cylindrical with thin subcutaneous tissue, joint dislocation, peripheral muscular atrophy and intact sensitivity. Joint deformities are bilateral and symmetric at both upper and down extremities in approximately $50 \%$ of newborns, genus articulation in $40 \%$ of cases, loop articulation in $5-10 \%$ (16). Skeletal anomalies as pectus exacavatum, pes equinovarus and scoliosis can also be present.

Some anomalies are more often such pulmonary hypoplasia, chriptorhysmus, or lack of labia majora, congenital heart diseases, tracheooesophageal fistula, cleft palate defect and inguinal haernia. It requires multidisciplinary access to manage complex and multiple disorders.

Table1. Differential diagnosis of arthrogryposis multiplex congenita

Amyoplasia

Beals syndrome

Cerebral palsy

Congenital muscular dystrophy

Fetal alkool syndrome

Intrauterine postural malformations

Potter's syndrome (renal agenesis)

Sacral agenesis

Schartz syndrome

Skeletal dysplasia

Spina bifida

Turner syndrome

Zellwenger syndrome

In our case there was not any urinary or genital disorder. From 10328 of all newborns in our Clinic for 2017, this was the only case with arthrogryposis multiplex congenita. Unfortunately, antenatal diagnosis has not been made, maybe due to the low the frequency of such cases. After birth, diagnosing has not been hard, but the treatment is very complex and difficult. By recommendations of orthopedics a hip screening is due to be performed by 4-6 weeks after delivery.

Treatment of these babies has to be planned in order for long term rehabilitation. Multidisciplinary involvement is essential for treatment in order to help in a partially contracture release.

Many children with arthrogryposis can be independent in finishing daily routine life activities, some others need help and possible surgical interventions in order to prevent deformities of extremities.

\section{CONCLUSION}

Arthrogryposis multiplex congenita is a disease that affects many joints and peri-articular tissues.

Very important for newborns with Arthrogryposis multiplex congenita to start with the physical therapy program, at the earliest stage after diagnosis. 
The purpose of early treatment is to provide as early as possible walking and to practice daily activities, respectively independent life.

Even in lack of in-utero diagnosis, a professional approach immediately after delivery makes survival of these group of newborns possible. Elimination of other possible accompanied anomalies, information and correct education of parents for the nature of disease is essential immediately after delivery.

\section{REFERENCES}

1. Ö. Kalenderer and B. Önvural, "Artrogripozis multipleks konjenita," TOTBİD Dergisi, vol. 8, pp. 3-4, 2009. View at Google Scholar

2. O. C. Baser, S. Ay, S. K. Dogan, and D. Evcik, "Multipl konjenital eklem kontraktürleri, artrogripozis multipleks konjenita: Bir olgu sunumu," Turkish Journal of Rheumatology, vol. 24, pp. 228-231, 2009.View at Google Scholar

3. C. Cinar, M. Sezgin, E. Aydog, and A. Cakci, "Multipl konjenital kontraktürler (artrogripozis multipleks konjenita)," Turkish Journal of Rheumatology, vol. 19, pp. 131-137, 2004. View at Google Scholar

4. Zeiter JH, Boniuk M. Ophthalmologic findings associated with arthrogryposis multiplex congenita: Case report and review of the literature. J Pediatr Ophthalmol Strabismus

5. Paez JH, Tuulonen A, Yarom R, ef al. Ocular findings in arthrogryposis multiplex congenita. J Pediatr Ophthalmol Strabismus 1982;19:75-9.

6. Callen PW. Ultrasonography in obstetrics and gynaecology. 3rded. Philadelphia: WB Saunders Company; 1994.

7. Izant RJ, Filston HC. Sacrococcygeal teratomas, analysis of fortythree cases. Am J Surg 1975; 130:617-620.

8. 4. Teal LN, Angtuaco TL, Jiminez JF, et al. Fetal teratomas antenataldiagnosis and clinical management. J Clin Ultrasound 1988;16:329-336.

9. Otto AW. Monstrum humanum extremitatibus incurvatus. Anntomico - Pathologieum Breslau;1841:322. Victor BA (trans). A human monster with inwardly curved extremities. Clin Orthop 1985;194:4-5.

10. Rocher HL. Les raideurs articulares conginitales multiples. J Med Bordeaux 1913;722:43.

11. Stern WG. Arthrogryposis multiplex congenita. JAMA 1923;81:1507.

12. Carol M Rumack, Stephanie R Wilson, J William Charboneau, Deorah Levine. The Fetal Musculoskeletal System by Phyllis Glanc, David Chitayat, and Sheila Unger- 4th Edition - Volume II/ 2005:1413-1415

13. Peter W Callen.The Fetal Musculoskeletal System by Luis F Goncalves, Juan Pedro Kusanovic, Francesca Gotsch, Jimmy Espinoza, Roberto Romero -5th Edition/2008: 469-470

14. Ibrahim A Alorainy, Nauman B Barlas, Amer A Al-Boukai. MULTIORGAN: Pictoral essay: Infants of diabetic mothers. Indian Journal of Radiology and Imaging.2010,20(3): 174-181.

15. Hall JG. Arthrogryposis. Am Fam Physician 1989;39:113-9.

16. Thompson GH, Bilenker RM. Comprehensive management of arthrogryposis multiplex congenita. Clin Orthop

Citation: Faton Krasniqi, Shpetim Salihu, Isabere Krasniqi, Edmond Pistulli, "Arthrogryposis Multiplex Congenita - Case Report". American Research Journal of Pediatrics. 2018; 2(1): 1-5.

Copyright (c) 2018 Faton Krasniqi, Shpetim Salihu, Isabere Krasniqi, Edmond Pistulli. This is an open access article distributed under the Creative Commons Attribution License, which permits unrestricted use, distribution, and reproduction in any medium, provided the original work is properly cited. 